\title{
OUTCROSSING ON HOMOSTYLE PRIMROSES
}

\author{
JACK L. CROSBY \\ Botany Department, Durham Colleges in the University of Durham
}

\section{INTRODUCTION}

Bodmer (1958) gives figures which he claims demonstrate that homostyle primroses (Primula vulgaris) are cross-fertilised in cultivation to the extent of about 80 per cent., and he considers that this is also true of homostyles in wild populations. My own results from primroses both in the wild and in cultivation lend no support to this view. Indeed, they strongly suggest a much lower rate of cross-fertilisation, as this note will show.

Bodmer's estimate of outcrossing is based on the following observation, made over a number of years. Families grown from seed set by open pollination of heterozygous homostyles were found to have a significant deficiency of pins, when compared with the expectation that the same plants on selfing would have segregated one pin : three homostyles. His parent plants were grown in an open bed in which one third of the homostyles are stated to have been homozygous. He therefore concludes that the shortage of pins arose from cross-pollination, the presence of homozygous homostyles among the potential pollinators producing excess of homostyles among the progeny of the heterozygotes. This attempt to estimate the amount of outcrossing depends directly on the assumption that heterozygous homostyles on selfing always segregate to give 25 per cent. of pins. My own results, however, show that in many cases, possibly in most, there is a clear deficiency of pin plants in families from controlled self-pollination of heterozygous homostyles.

\section{ESTIMATION OF OUTCROSSING IN CULTIVATION}

A much more direct and accurate way of determining the extent of cross-fertilisation of homostyles under garden conditions is to grow them in a bed containing thrums (which will donate pollen as readily as homostyles in cross-pollination), and to collect their seeds and grow families from them. Every thrum appearing among the progeny is a definite indication of a foreign pollen grain.

In 1948, 54 capsules were taken from i4 homostyles ( 6 heterozygous, 8 homozygous), growing in a bed containing 203 pins (ss), I 76 thrums $(S s), 3$ I heterozygous homostyles $\left(s^{\prime} s\right)$, and I2 homozygous homostyles $\left(s^{\prime} s^{\prime}\right)$. The homozygous homostyles were together near one end of the bed ; the other types were distributed more or less evenly through the bed. Table I shows the progeny : the rather poor germination was common to almost all families sown at the same time as these. Of the 568 plants produced, only I 7 were thrums; of these 9 came from one capsule and 4 from a second. Since about 40 per cent. of the available high-anther pollen would carry $S$, the 17 thrums represent about 7.5 per cent. of cross-fertilisation of the homostyles. The only alternative possibility would be a high death rate among thrum-homostyle heterozygotes $\left(S s^{\prime}\right)$, but this is contradicted by the fact that of the thrum plants which did appear, all but 2 came from 
homozygous homostyles which can produce only $S s^{\prime}$ thrums; while of approximately I I $5 s$ ovules on heterozygotes, not more than 2 were fertilised by $S$ grains. Also, a few small families from crosses between thrums and homozygous homostyles actually show an excess of thrums over homostyles. It is clear that any inviability which there may be of $S s^{\prime}$ zygotes is insufficient to require any large amendment of the estimate of outcrossing.

TABLE I

Open pollination of homostyles in a bed containing 203 pins, 176 thrums, $3^{1}$ heterozygous homostyles, and 12 homozygous homostyles.

\begin{tabular}{|c|c|c|c|c|c|}
\hline Plant & $\begin{array}{l}\text { Distance from homozygous } \\
\text { homostyles, in feet }\end{array}$ & $\begin{array}{l}\text { No. of } \\
\text { capsules }\end{array}$ & $\mathbf{P}$ & Progen & $\mathrm{H}$ \\
\hline \multicolumn{6}{|c|}{$\begin{array}{l}\text { Heterozygous homostyles } \\
\mathrm{D}, \mathrm{E}, \mathrm{F} \text { are sister plants }\end{array}$} \\
\hline $\begin{array}{l}\mathrm{A} \\
\mathrm{B} \\
\mathrm{C} \\
\mathrm{D} \\
\mathrm{E} \\
\mathrm{F}\end{array}$ & $\begin{array}{r}16 \\
12 \\
7 \\
3 \\
3 \\
3\end{array}$ & $\begin{array}{r}7 \\
4 \\
5 \\
4 \\
3 \\
8 \\
3^{1}\end{array}$ & $\begin{array}{r}10 \\
2 \\
9 \\
5 \\
11 \\
14 \\
51\end{array}$ & $\begin{array}{l}0 \\
0 \\
0 \\
1 \\
0 \\
1 \\
2\end{array}$ & $\begin{array}{l}43 \\
21 \\
40 \\
18 \\
25 \\
33 \\
180\end{array}$ \\
\hline \multicolumn{6}{|c|}{ Homozygous homostyles ; sister plants } \\
\hline $\begin{array}{l}\mathrm{G} \\
\mathrm{H} \\
\mathrm{I} \\
\mathrm{J} \\
\mathrm{K} \\
\mathrm{L} \\
\mathrm{M} \\
\mathrm{N}\end{array}$ & & $\begin{array}{l}2 \\
2 \\
2 \\
2 \\
5 \\
3 \\
3 \\
4\end{array}$ & $\begin{array}{l}\cdots \\
\cdots \\
\cdots \\
\cdots \\
\cdots \\
\cdots \\
\cdots\end{array}$ & $\begin{array}{l}\text { o } \\
\text { I } \\
0 \\
0 \\
\text { I } \\
9^{*} \\
0 \\
4^{*}\end{array}$ & $\begin{array}{l}38 \\
26 \\
36 \\
30 \\
82 \\
38 \\
26 \\
44\end{array}$ \\
\hline & & 23 & $\cdots$ & 15 & 320 \\
\hline & Grand totals & 54 & $5^{I}$ & 17 & 500 \\
\hline
\end{tabular}

* All from one capsule.

Closer examination of table I shows that 3 of the heterozygotes, A, B and $\mathrm{C}$, actually produced a greater shortage of pins (taken together) than all but the first two years of Bodmer's results. The total for $\mathrm{A}, \mathrm{B}, \mathrm{C}$ is 2 I pins : I04 homostyles which differs significantly from a I : 3 ratio $\left(\chi_{[\mathrm{r}]}^{2}=4.5\right)$; it may be considered separately from the total for $\mathrm{D}, \mathrm{E}, \mathrm{F}$, since the two totals are probably heterogeneous $\left(\chi^{2}{ }_{[r]}=4 \cdot I\right)$.

The shortage of pins from A, B, C can hardly have been due to outcrossing by homozygous homostyles, since there were far more thrums than homostyles in the bed, and there is no evidence of outcrossing by thrums onto these 3 plants. Moreover, they were much farther from the homozygous homostyles than D, E, F, which have no deficiency of pins. The possibility that one or two exceptional cross-pollinations by homozygous homostyles may have seriously upset the ratio may be ruled out, since the deficiency of pins was shown by 13 of the 16 capsules. The most likely explanation is that the 3 plants would have shown a similar deficit of pins 
on controlled self-pollination, and that the plants D, E and F (which were sister plants) differed from them in this respect.

\section{PROGENY FROM CONTROLLED POLLINATIONS}

That this deficit of pins is a general phenomenon of $F_{2}$ families from heterozygous homostyles is shown by table 2, which gives the results of controlled self-pollinations and of crosses between heterozygous homostyles. The figures include all appropriate families for which data are available, and are grouped according to the experimental series in which they were carried out.

TABLE 2

Controlled pollinations of heterozygous homostyles

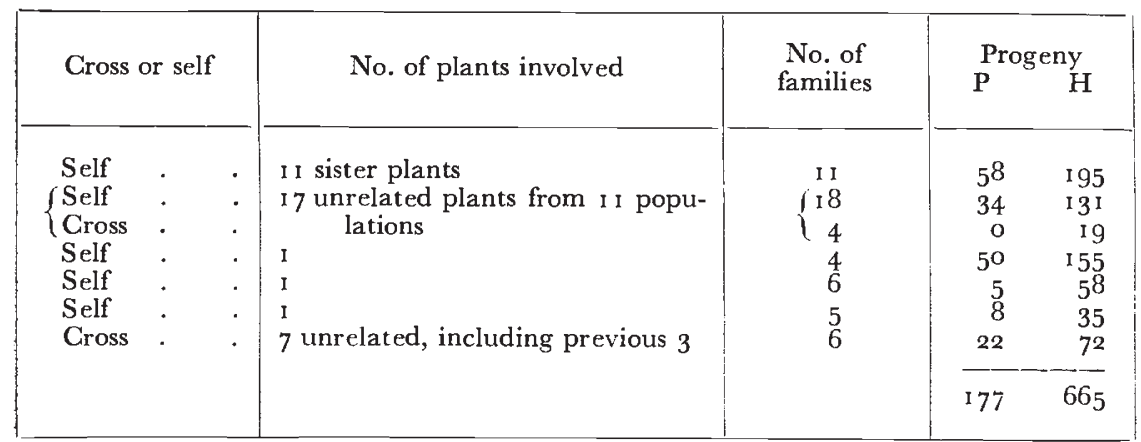

The total shows a significant shortage of pins from the expected I : 3 $\left(\chi^{2}{ }_{[\mathrm{I}]}=7 \cdot \mathrm{r}\right)$, but the close correspondence with the ratio of Bodmer's total is presumably a coincidence, since the individual series are probably heterogeneous $\left(\chi_{{ }^{\prime}[6]}^{2}=14^{\circ} \mathrm{O}\right)$. These results strongly support the suggestion from the open-pollinated families that many heterozygous homostyles show a considerable deficit of pins on selfing, and that there is variability in this respect among different plants.

Bodmer's results are most reasonably explained on this basis. It is true that he allowed some heterozygotes to self, and obtained 130 pins to 390 homostyles. But this ratio is based only on segregating families; we are not told the size of the families used, so we have no means of estimating how many families from heterozygotes might have been excluded because no pins appeared in them ; the result will, however, be taken at its face value.

These $F_{2}$ families were produced in 1956 and 1957 , that is after the latest and much the largest of Bodmer's open-pollinated progeny groups had shown not merely no deficiency, but a slight excess of pins. In the absence of specific information in Bodmer's paper, it would seem reasonable to infer that these families are most nearly related to the most recent of his openpollinated series. That is, as controls they are most relevant to his large I 955 score, with its slight excess of pins, and their relevance decreases as one goes back in time. Yet in carrying out a contingency test, he omits the 1955 plants and tests the $F_{2}$ against the doubtfully relevant earlier results.

It seems most likely that the earlier plants had a tendency to an $\mathrm{F}_{2}$ shortage of pins, and that this tendency decreased until it became slight 
by the time the 1955 families and the subsequent $\mathrm{F}_{2}$ families were produced. Even if we exclude the 1955 results, the others still suggest a trend in this direction.

If Bodmer wishes to establish his interpretation, he must demonstrate that the earlier plants would have segregated $x: 3$ on selfing, and that the deficit of pins in the open-pollinated families was matched by an excess of homozygous homostyles. The latter point is critical ; the only evidence which Bodmer offers is that he found no significant difference from a homozygote : heterozygote ratio of $I: 2$, and he himself assumes this ratio in his calculations. An extensive series of test-crosses is called for. Bodmer makes no real attempt to explain why there should have been no crosspollination in 1955 .

But whatever the validity of Bodmer's results may be, the application of conclusions drawn from cultivated families to natural populations requires. the greatest caution. Conditions are different. As a case in point, we may consider his observation that in his plants the stigma is frequently to be seen above the anthers in young flowers. Now plants grown in cultivation normally flower at least two or three weeks before their wild counterparts, when the weather is relatively colder. Under these conditions, and under the usually exposed conditions of the garden bed, the corolla tube (which is usually much more sensitive to ordinary environmental changes than the style) is relatively short, and any tendency of the stigma to project is enhanced. I have noticed this in a number of my own families. This situation has little relevance to natural conditions. I must have examined nearly 50,000 wild homostyle flowers; a large proportion of these will have been opening buds or newly-opened flowers, since where there is any choice it is these that are taken for examination. It can be stated quite definitely that in newly-opened flowers it is unusual for the stigma to be visible above the anthers, and rare for it to be entirely clear of them.

Bodmer found a delay of some days in anther dehiscence in many of his cultivated plants, but presents no evidence to show that pollinating insects ever visit primroses before the flowers are fully open and the anthers have dehisced. His observations were made in hot sunny weather; but hot sunny spring days are often accompanied by very cold nights, especially in Cambridge. In my experience of natural populations, delay in anther dehiscence is unusual except in the sort of weather in which very few pollinators are flying.

\section{ESTIMATION OF OUTCROSSING IN NATURAL POPULATIONS}

One method of estimating the amount of outcrossing on wild homostyles is on the basis that cross-fertilisation by thrums will produce some plants of constitution $S s^{\prime}$, that is thrum-homostyle heterozygotes. Such plants should be found in natural populations if homostyles are regularly crosspollinated. The actual existence of such plants, and their implications, has already been pointed out (Crosby, 1949). Detailed results can now be given.

Test crosses have been made on 95 thrum plants from I 7 populations of roughly comparable constitution chosen as likely to show the highest proportion of $S s^{\prime}$ plants ; the average homostyle content was about 52 per cent. It can be shown that, with 80 per cent. outcrossing, about 20 of the 
tested thrums should have been $S s^{\prime}$. The actual number was 2 ; the remaining 93 were $S s$. This direct attempt to estimate outcrossing on homostyles in natural conditions suggests a value lying between 5 and Io per cent., and this value must carry more weight than Bodmer's indirect and doubtfully valid estimation on cultivated plants descended from a few plants taken originally from a single locality.

Finally, it is difficult to see how the very marked shortage of thrums as compared with pins which is found in populations with many homostyles (Crosby, I949) can be accounted for other than by supposing thrum pollen to be at a serious disadvantage as compared with homostyle pollen, and this can only result from a high frequency of self-pollination of homostyles. The whole question of pollination and fertilisation of the primrose has been carefully studied by several quite different methods, and an account of this work is in course of preparation. It will include a discussion of the deficit of pins which is found on selfing heterozygous homostyles.

\section{SUMMARY}

Bodmer's indirect estimate of a high frequency of outcrossing among homostyle primroses (Primula vulgaris) is questioned on the following grounds.

Heterozygous homostyles on controlled self-pollination commonly produce less than the expected 25 per cent. of pins; this conflicts with the basic assumption of Bodmer's calculations, and offers a likely explanation of his results.

The use of thrums as direct indicators of outcrossing has given experimental evidence of about 7.5 per cent. outcrossing of homostyles under garden conditions.

On a similar basis, an estimate of outcrossing on homostyles under natural conditions, involving I7 populations, suggests a value between 5 and io per cent.

The known constitutions of populations containing homostyles require for their explanation a considerable competitive disadvantage of thrum pollen, and this can hardly arise except through a high degree of selffertilisation of homostyles.

\section{REFERENCES}

Bodmer, w. F. 1958. Natural crossing between homostyle plants of Primula vulgaris. Heredity, I2, 363-370.

CRosbx, J. L. 1949. Selection of an unfavourable gene-complex. Evolution, 3, 212-230. 